\title{
Lake-level history of Lake Tanganyika, East Africa, for the past 2500 years based on ostracode-inferred water-depth reconstruction
}

\author{
Simone R. Alin*, Andrew S. Cohen \\ Department of Geosciences, University of Arizona, Tucson, AZ 85721, USA
}

Received 25 April 2002; accepted 28 May 2003

\begin{abstract}
Assemblages of ostracodes from sediment cores illuminate lake-level history at decadal to centennial timescales during the late Holocene at Lake Tanganyika, East Africa. The ostracode-based lake-level curves for several cores resemble both each other and the only previously published lake-level record of comparable resolution for Lake Tanganyika during this interval, successfully reconstructing known highstands, improving the chronology of known lowstands, and contributing new information on late Holocene lake-level variability at this important tropical African location. In agreement with other late Holocene records from East Africa, the surface level at Lake Tanganyika reflects predominantly arid conditions throughout this interval, interrupted by relatively brief episodes of higher precipitation and lake level. The most pronounced lowstand in the record occurs at $\sim 200-0 \mathrm{BC}$, with other significant lowstands dating to the intervals $\sim 200-500 \mathrm{AD}, \sim 700-850 \mathrm{AD}$, the Medieval Warm Period (MWP; $\sim 1050-1250 \mathrm{AD}$ at Lake Tanganyika), and the latter part of the Little Ice Age (LIA; 1550-1850 AD). The most important wet intervals in the lake-level record are centered on $\sim 500 \mathrm{AD}, \sim 1500 \mathrm{AD}$, and $\sim 1870 \mathrm{AD}$. The highstands and lowstands reported here for Lake Tanganyika appear to be fairly coherent with other records of rainfall throughout East Africa during the MWP and the LIA. Prior to the MWP, paleoclimate records are apparently less coherent, although this may be a reflection of the resolution and abundance of recent paleoclimatic data available for this climatically complex region.
\end{abstract}

(c) 2003 Elsevier B.V. All rights reserved.

Keywords: paleoclimate; Lake Tanganyika; East Africa; ostracodes; paleolimnology; multivariate analysis

\section{Introduction}

Broad-scale reconstruction of paleoclimatic

* Corresponding author. Present address: Large Lakes Observatory, University of Minnesota, 10 University Drive, Duluth, MN 55812, USA. Fax: +1-218-726-6979.

E-mail address: simone.aline@stanfordalumni.org (S.R. Alin). conditions in East Africa during the late Holocene has been hindered by the paucity of sufficiently resolved records of climate change. Recent efforts have improved the coverage of paleoclimatic records for this region (cf. Johnson et al., 2001, 2002; Verschuren, 2001, in press; Verschuren et al., 2000), although coherency among rainfall patterns in different areas of East Africa is highly variable at both short and long timescales, render- 
ing generalization of paleoclimatic reconstructions from one site to another unreliable (Nicholson, 1996, 2000). In addition, many potential paleoclimatic records (e.g. pollen, stable isotopes, lacustrine microflora and microfauna) may bear signatures of anthropogenic overprinting of their respective climate signals for recent millennia in this cradle of human evolution. We offer here a new record of the lake-level and paleoenvironmental history of Lake Tanganyika during the late Holocene, based on ostracode assemblages in shallow-water sediment cores collected from sparsely populated stretches of the lakeshore. This contribution improves upon the temporal resolution of a previously published lake-level curve for Lake Tanganyika, which relied on stromatolitic and stable isotopic evidence to reconstruct highstands between $\sim 1250$ and $1550 \mathrm{AD}$ and at $430 \pm 110 \mathrm{AD}$ and lowstands of $-15-40 \mathrm{~m}$ (deviation from current average lake level) at some time after the late 5th century AD and between the late 16th and early 19th centuries AD (Cohen et al., 1997b).

Lake Tanganyika, East Africa, is a large $\left(32600 \mathrm{~km}^{2}\right)$, deep $\left(z_{\max }=1470 \mathrm{~m}\right)$, meromictic, tropical $\left(3-9^{\circ} \mathrm{S}\right)$ rift lake (Fig. 1). The surface level of the lake fluctuates at a variety of time and depth scales in response to both climatic and geomorphic factors. On an interannual to decadal scale, the surface of Lake Tanganyika has varied on the scale of a few meters during the 1900s (range: 772.5-776.7 $\mathrm{m}$ asl [meters above sea level], average $[ \pm$ S.D. $]=774.4 \pm 0.8 \mathrm{~m}$ asl; data for 1900-1999 AD from Evert, 1980; Birkett et al., 1999). However, lake levels were substantially higher in the mid-late 1800 s, experiencing a maximum highstand of $784 \mathrm{~m}$ asl in $1878 \mathrm{AD}$, as a function of both higher rainfall and alluvium plus vegetation blocking the lake's outlet. Finally, the surface level of Lake Tanganyika has undergone even more extreme variation, on the order of tens to hundreds of meters, in response to climatic and tectonic forcing at timescales of millennia and longer (cf. Cohen et al., 1997a; Haberyan and Hecky, 1987; Talbot, 2001). It is worthwhile noting that because of the immense area of the lake and its catchment, changes in climatic conditions may be manifested as a change in lake level after a temporal lag of a few months to decades, although the importance of this phenomenon will depend on the timescale of the analysis at hand.

The species composition of paleoecological ostracode assemblages can be used to reconstruct lake-level fluctuations through time at high resolution in lacustrine ecosystems. Previous studies have relied on detailed information on depth and salinity tolerances of constituent species (e.g. Forester et al., 1994), or on extensive collections of species assemblages throughout a calibration set of lakes with variant modern depth and salinity regimes (e.g. Mourguiart and Carbonel, 1994), as a basis for paleolake-level reconstruction. Typically, these investigators have relied on the ecological significance of the relative abundances of common species through time as an indicator of lake level, as interpreted through use of a simple water-depth index or through multivariate techniques.

In cases such as Lake Tanganyika, ecological tolerances of individual ostracode species are unknown or difficult to determine. Lake Tanganyika boasts an estimated 200 species of microcrustacean ostracodes, with levels of endemism on the order of 70\% (Martens, 1994). Local endemism, species richness, and spatiotemporal heterogeneity in the distributions of the component species are high, such that defining a water-depth index based on the abundance of a few select species would not yield a widely applicable index of lake-level change throughout the lake basin. Detailed depth tolerance data are available for very few Tanganyikan ostracode species, but most species do show peaks in abundance over finite depth ranges (on the scale of meters to a few tens of meters). Thus, ostracode species assemblages en masse should inherently contain basic ecological information, such as relative depth preferences, that can be useful in constructing paleolake levels. All Tanganyikan ostracodes are effectively benthic, with no truly pelagic species found in the lake, and are currently limited to inhabiting the upper 100-200 $\mathrm{m}$ of the water column, where dissolved oxygen is available. Thus, we expect that ostracode assemblages will vary substantially with relative water depth in Lake Tanganyika. 
Because ostracodes are preserved abundantly and in high quality in sediment cores from the lake, it should be possible to reconstruct relative lake level from the sediment record of ostracode species composition.

\section{Methods}

\subsection{Core collection and sampling}

The 2500-year reconstruction of relative lake level described here for Lake Tanganyika comes from core LT-97-56V, a $356 \mathrm{~cm}$ vibracore collected in $56 \mathrm{~m}$ water depth. The coring site is about $700 \mathrm{~m}$ southeast of a small river outlet draining a watershed of $5.7 \mathrm{~km}^{2}\left(5^{\circ} 46.33^{\prime} \mathrm{S}\right.$, $29^{\circ} 56.03^{\prime} \mathrm{E}$; Fig. 1). The coring site is near the village of Mgondozi, Tanzania, but human population density is low in this area of the Tanganyika basin $\left(\sim 17\right.$ people $/ \mathrm{km}^{2}$; President's Office Planning Commission, 1991). Visual inspection of the core at the time of collection and subsequent $\mathrm{X}$-radiography indicated that it experienced minimal disturbance during the coring process, and the core top appeared to be intact upon recovery. The core was cut into $150-\mathrm{cm}$ sections in the field, sealed, and shipped to the U.S. for further analysis. Subsequently, the core was split, X-radiographed, and sampled every other centimeter for the upper $20 \mathrm{~cm}$, and every fourth centimeter

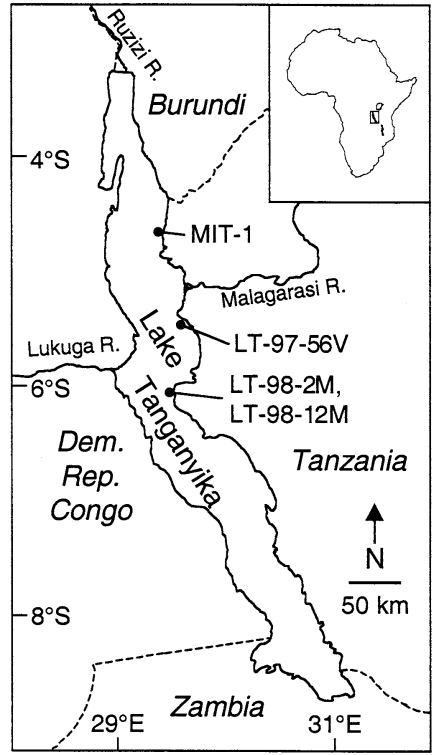

Fig. 1. Map of Lake Tanganyika with locations of all cores discussed in the text indicated. Inset box shows location of Lake Tanganyika within Africa.

thereafter. Every other sample was analyzed for grain-size distribution, sedimentary organic matter (SOM) and carbonate content, and ostracode assemblage composition (i.e. every fourth centimeter was analyzed to $20 \mathrm{~cm}$, every eighth centimeter thereafter). A gas gap of $13 \mathrm{~cm}$ was found in the core between 56 and $70 \mathrm{~cm}$. This length was excised from all core data sets such that all figures

Table 1

Radiocarbon dates for core LT97-56V from Lake Tanganyika

\begin{tabular}{llccccc}
\hline $\begin{array}{l}\text { Sample } \\
\text { number }\end{array}$ & $\begin{array}{l}\text { Material } \\
\text { dated }\end{array}$ & $\begin{array}{l}\text { Depth in } \\
\text { core } \\
(\mathrm{cm})\end{array}$ & $\begin{array}{l}\text { Fraction } \\
\text { modern }{ }^{14} \mathrm{C}\end{array}$ & ${ }^{14} \mathrm{C}$ age & $\begin{array}{l}2 \sigma \text { calendar } \\
\text { age range } \\
\text { (yr BP })\end{array}$ & $\begin{array}{l}\text { Area under } \\
\text { probability curve }\end{array}$ \\
\hline AA-43467 & single leaf & $0-1$ & $0.9606 \pm 0.0055$ & $323 \pm 46$ & $483-297$ & 1.000 \\
AA-43468 & single leaf & $2-3$ & $0.9834 \pm 0.0047$ & $134 \pm 39$ & $279-171$ & 0.423 \\
& & & & & $152-51$ & 0.405 \\
& & & & $45-6$ & 0.153 \\
AA-28408 & plant fragments & $17-18$ & $0.9615 \pm 0.0055$ & $315 \pm 45$ & $477-293$ & 1.000 \\
AA-43385 & single leaf & $50-51$ & $0.9582 \pm 0.0041$ & $343 \pm 34$ & $480-310$ & 1.000 \\
AA-27665 & plant fragments & 92 & $0.9203 \pm 0.0070$ & $667 \pm 61$ & $693-540$ & 1.000 \\
AA-43469 & single leaf & $162-63$ & $0.7825 \pm 0.0077$ & $1970 \pm 79$ & $2117-1726$ & 1.000 \\
AA-43470 & single leaf & $198-99$ & $0.7017 \pm 0.0053$ & $2846 \pm 61$ & $3082-2840$ & 0.869 \\
AA-43471 & single leaf & $242-43$ & $0.6067 \pm 0.0070$ & $4014 \pm 93$ & $4735-4240$ & 0.904 \\
AA-43472 & single leaf & $298-99$ & $0.5425 \pm 0.0098$ & $4910 \pm 140$ & $5928-5438$ & 0.916 \\
AA-43473 & single leaf & $322-23$ & $0.2836 \pm 0.0048$ & $10120 \pm 140$ & $12392-11261$ & 0.938
\end{tabular}

\footnotetext{
a All calibrated ages representing $\geq 0.100$ relative area under the probability distribution are reported.
} 
reflect a total core length of $343 \mathrm{~cm}$ with continuous records.

\subsection{Geochronology and sedimentology}

Ten radiocarbon dates for LT-97-56V were based on terrestrial plant fragments to avoid the problem of ${ }^{14} \mathrm{C}$-reservoir age for samples produced within the lake (Table 1). Leaf and wood samples were prepared for radiometric analysis by acid-base-acid pretreatment to remove carbonates and diagenetic organic material. All radiocarbon analyses were made by the Arizona AMS Laboratory. Calibrated radiocarbon ages were assigned using CALIB 4.3 (Stuiver et al., 1998a,b). The Southern Hemisphere correction was not applied, because the study site is equatorial. Existing data on interhemispheric concentration differences in atmospheric ${ }^{14} \mathrm{C}$ provide inconclusive evidence on the relevance of the Southern Hemisphere correction to southern equatorial locations. It is possible that this relationship has changed with the southern migration of the Intertropical Convergence Zone (ITCZ) through the Holocene (Haug et al., 2001), but the magnitude of any difference in the resulting age model should be trivial.

For the purpose of establishing an age model for core LT-97-56V, midpoints of the most probable calibrated age ranges $(2 \sigma)$ were used, except for the sample from 2-3 cm (Fig. 2). For this sample, the second-most probable age provided an age model more consistent with our observation of an intact core top and was of essentially equivalent probability to the most probable calibrated age. Calendar ages were assigned to stratigraphic intervals based on a second-order polynomial fit of the calibrated radiocarbon data. The uppermost and lowermost radiocarbon dates were excluded from the age model on the basis of apparent reworking and a depositional hiatus, respectively. Calibrated radiocarbon ages are reported in calendar years $\mathrm{AD}$ or $\mathrm{BC}$ and/or in $\mathrm{yr}$ $\mathrm{BP}$ (yr BP = calendar years before present, where 'present' is $1950 \mathrm{AD}$ by radiocarbon convention).

Concentrations of SOM and carbonate $\left(\mathrm{CO}_{3}\right)$ were estimated by loss-on-ignition at 550 and $925^{\circ} \mathrm{C}$, respectively (Bengtsson and Enell, 1986).

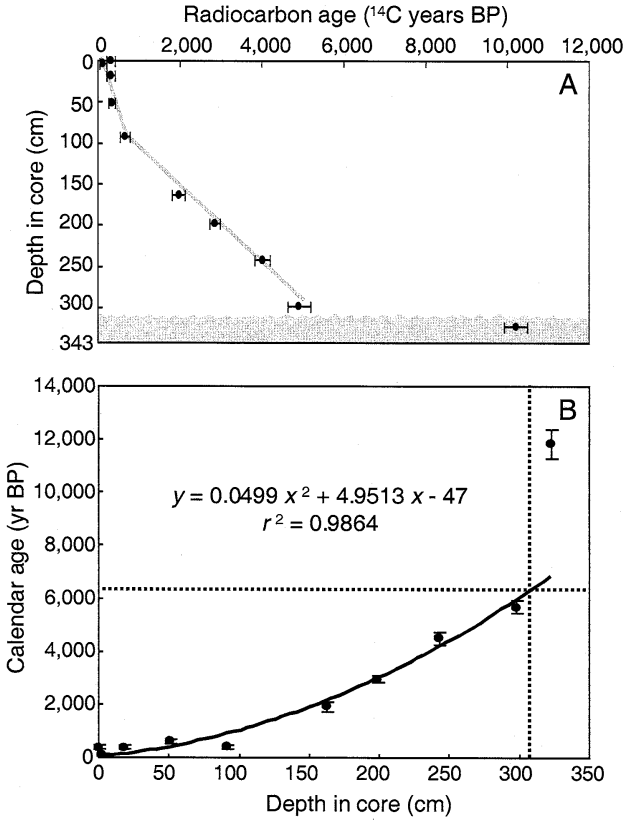

Fig. 2. Depth-age relationships for core LT-97-56V. (A) Radiocarbon ages for dated samples with associated error bars. Sedimentary layers below the depositional hiatus are indicated by gray shading and wavy erosional surface. Gray lines represent zones of similar sedimentation rates in the core but do not represent an age model. (B) Calendar-year age model for core LT-97-56V. Error bars on individual dates are indicated. Location of the depositional hiatus is shown by dashed horizontal and vertical lines.

Remaining sediments were sieved using $1 \mathrm{~mm}, 106$ $\mu \mathrm{m}$, and $63 \mu \mathrm{m}$ mesh sieves, with the finest fraction of sediment $(<63 \mu \mathrm{m})$ retained on Whatman-1 qualitative filter paper. All samples were dried at $40^{\circ} \mathrm{C}$.

\subsection{Paleoecology}

Ostracodes from the $>1 \mathrm{~mm}$ sediment fraction were added to the $106 \mu \mathrm{m}-1 \mathrm{~mm}$ fraction before sediment splits of the $106 \mu \mathrm{m}-1 \mathrm{~mm}$ sediment fraction were counted for ostracodes. For all samples containing sufficient ostracodes, 500 individuals were identified to the species level following published descriptions to the extent possible (Martens, 1985; Park and Martens, 2001; Rome, 1962; Wouters, 1979, 1988; Wouters and Martens, 1992, 1994, 1999, 2001; Wouters et al., 1989). As roughly half of the estimated 200 Tan- 

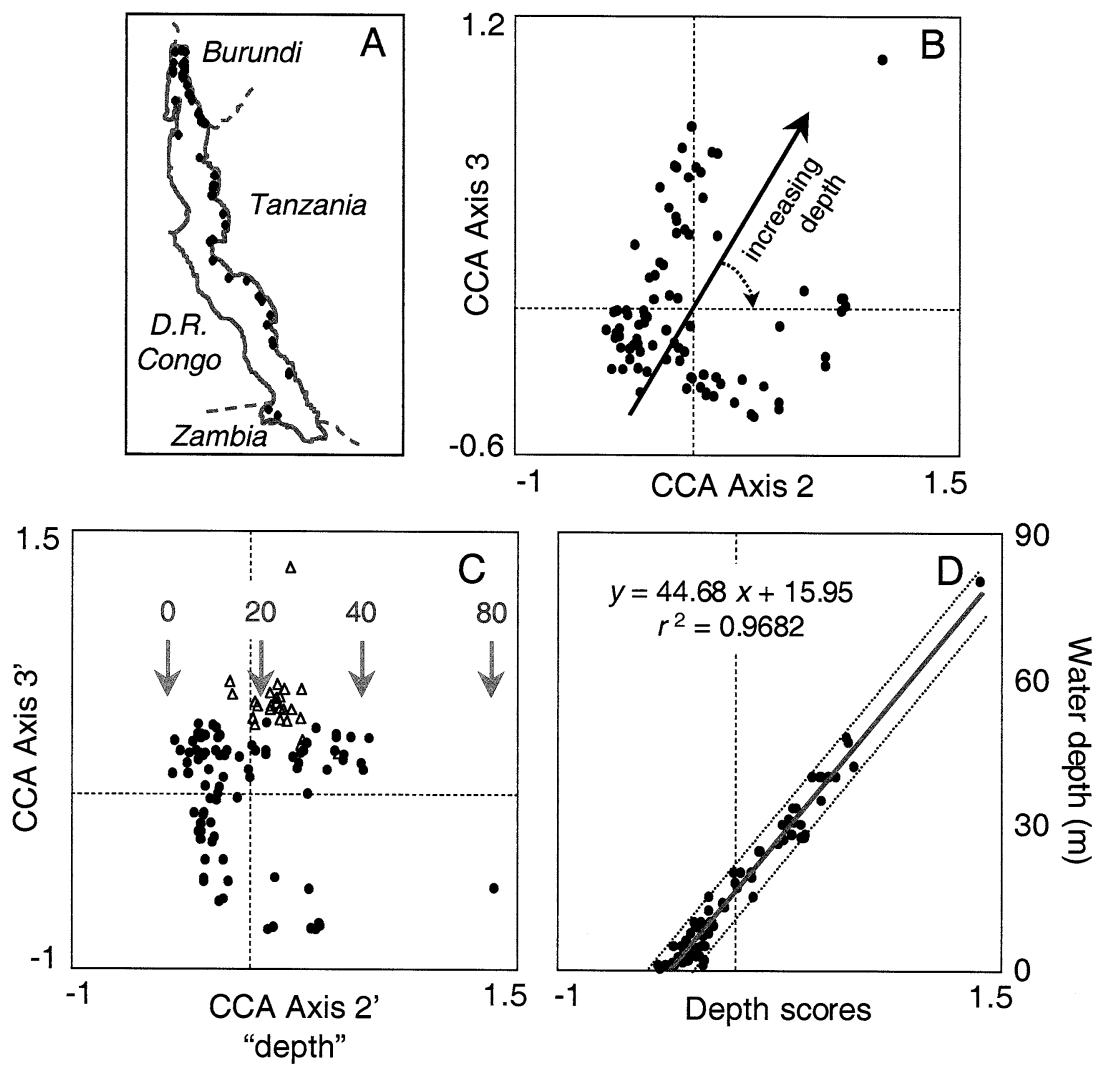

Fig. 3. CCA of live ostracode database. (A) Geographic coverage of live ostracode assemblages included in analysis, with sample locations indicated by black diamonds $(n=86)$. Many diamonds, particularly in the northern basin of Lake Tanganyika, overlap each other. (B) Distribution of live ostracode samples, marked by black circles, in CCA ordination space. The solid arrow indicates the approximate location of the diagonal depth-related axis. The dashed arrow shows how the 'depth' axis was subsequently rotated. (C) A view of the CCA plot, with coordinates and axes rotated. Black circles represent live ostracode assemblages, open triangles indicate assemblages from core LT-97-56V. Gray arrows and numbers show the approximate water depths where samples in the ordination plot were collected. (D) The relationship between depth scores of live ostracode samples and the water depth at which the samples were collected. The gray line shows the linear regression of these data and is represented by the equation above. Dashed lines are $95 \%$ confidence intervals around the regression.

ganyikan ostracode species remain to be described (Martens, 1994), extensive reference collections at the University of Arizona were employed to assign identities to specimens from undescribed species, using a system of informal numeric monikers to name taxa (species list in Appendix 1).

\subsection{Relative water-depth reconstruction}

Relative water depth, and therefore lake level, was reconstructed based on the output of a canonical correspondence analysis (CCA) of ostracode species-abundance data for live-collected samples from various sites, habitats, and depths in Lake Tanganyika. Prior to analyzing the live species-abundance data, all singletons and doubletons by occurrence (i.e. all species occurring in only one or two samples) were excluded from the database, leaving 93 species in the calibration analysis (Appendix 1). This live calibration database consists of 86 samples (Fig. 3A). Environmental variables included substrate type (rocks, sand, mud), water depth $(0.3-80 \mathrm{~m})$, latitude $\left(3.35^{\circ}-8.48^{\circ} \mathrm{S}\right)$, longitude $\left(29.15^{\circ}-30.78^{\circ} \mathrm{E}\right)$, watershed disturbance level (low, moderate, high), and vegetation type (algae, macrophytes, stromato- 
lites, none). CCA was performed using CANOCO 4 (ter Braak and Smilauer, 1998). CCA Axis 1 was significantly and strongly correlated with substrate type $(r=+0.67)$ and weakly with longitude $(r=+0.22)$. CCA Axis 2 correlated significantly with latitude $(r=+0.80)$, water depth $(r=+0.36)$, and substrate type $(r=-0.19)$; CCA Axis 3 with water depth $(r=+0.74)$ and disturbance level $(r=+0.20)$; and CCA Axis 4 with vegetation type $(r=+0.42)$, disturbance level $(r=-0.41)$, and substrate type $(r=+0.20)$. The first four canonical axes cumulatively explain $7.0 \%, 11.2 \%, 14.6 \%$, and $16.4 \%$ of the variance in the species-abundance data.

Relative water depths were constructed as follows. First, samples were plotted in CCA Axis 2 vs. Axis 3 ordination space to maximize dispersion of samples according to water depth (Fig. 3B). In ordination space, live samples were arrayed by depth along a diagonal axis. All ostracode assemblages from core samples were included in the CCA as 'supplementary' samples, meaning that their species-abundance data did not contribute to the gradient analysis. Rather, CANOCO assigned ordination scores to coresample assemblages in a post hoc fashion, allowing them to be plotted in the same ordination space as the live ostracode samples. Second, all coordinates were rotated, such that the diagonal depth axis in Fig. 3B became the new horizontal axis (CCA Axis 2' or 'depth' axis in Fig. 3C). For all live samples, sample scores on the new depth axis (hereafter referred to as 'depth scores') are tightly correlated with the actual depth at which samples were collected, suggesting that depth is a sufficiently strong environmental parameter in structuring living ostracode assemblages that we may be able to reconstruct relative changes in water depth using paleoecological ostracode assemblages (Fig. 3D).

We compared the lake-level curve generated from LT-97-56V with lake-level reconstructions based on ostracode data from three additional cores to assess the effects of core location and water depth on lake-level reconstruction. Cores LT-98-2M and LT-98-12M were collected offshore from Mahale Mountains National Park in west central Tanzania (LT-98-2M, $110 \mathrm{~m}$ water depth, $49 \mathrm{~cm}$ length; LT-98-12M, $126 \mathrm{~m}, 40 \mathrm{~cm}$; data from Cohen et al., 1999), and core MIT-1 was taken offshore from Gombe Stream National Park in northwestern Tanzania (MIT-1, $15 \mathrm{~m}$ water depth, $18 \mathrm{~cm}$ length; data from Alin, 2001). Human population density in both national parks is $<5$ people $/ \mathrm{km}^{2}$ (Cohen et al., 1999), so anthropogenic impact on the water-depth fidelity of ostracode assemblages should not be a concern. Chronologies for cores were established by radiocarbon-dating samples of terrestrial material contained in horizons in the sediment cores (cores LT-98-2M, LT-98-12M, and MIT-1 had four, two, and three ${ }^{14} \mathrm{C}$ dates, respectively; Alin et al., 2002; Cohen et al., 1999). The chronology for LT-98-2M is based on a third-order polynomial fit of the most probable calibrated ages for the four ${ }^{14} \mathrm{C}$ dates, which gives a core-top age of $\sim 1790$ AD. For the purposes of this paper, the calibrated radiocarbon dates used to generate the age models for cores LT-98-12M and MIT-1 were not necessarily the most probable calibrated ages, but gave results most consistent with other physical and faunal evidence. Cores LT-98-2M and LT-98-12M had low sediment mass-accumulation rates (MARs) throughout (average LT-98-2M MAR $=0.007 \pm 0.005 \mathrm{~g} \mathrm{~cm}^{-2} \mathrm{yr}^{-1} ;$ LT-98-12M $\mathrm{MAR} \approx 0.03 \mathrm{~g} \mathrm{~cm}^{-2} \mathrm{yr}^{-1}$ ) and were sampled every third centimeter for ostracode assemblages (Cohen et al., 1999). MIT-1 appears to have been deposited entirely within the past 150 years. All $1-\mathrm{cm}$ core intervals were tallied for ostracodes in MIT-1, making it the highest-resolution record. We have the highest confidence in the chronology for core LT-97-56V, as it is anchored by 10 radiocarbon dates, with relatively little ambiguity about reworking through the interval containing ostracode assemblages. The chronology for core LT-98-2M also appears to be robust, although of lower resolution because of low sediment accumulation rates.

Depth scores for core assemblages were consistently offset from the depths at which the cores were collected (see Fig. 3C and Section 4). To facilitate comparison among water-depth curves generated for the various cores examined, we standardized depth scores for all cores by subtracting the depth-score average for a core from 


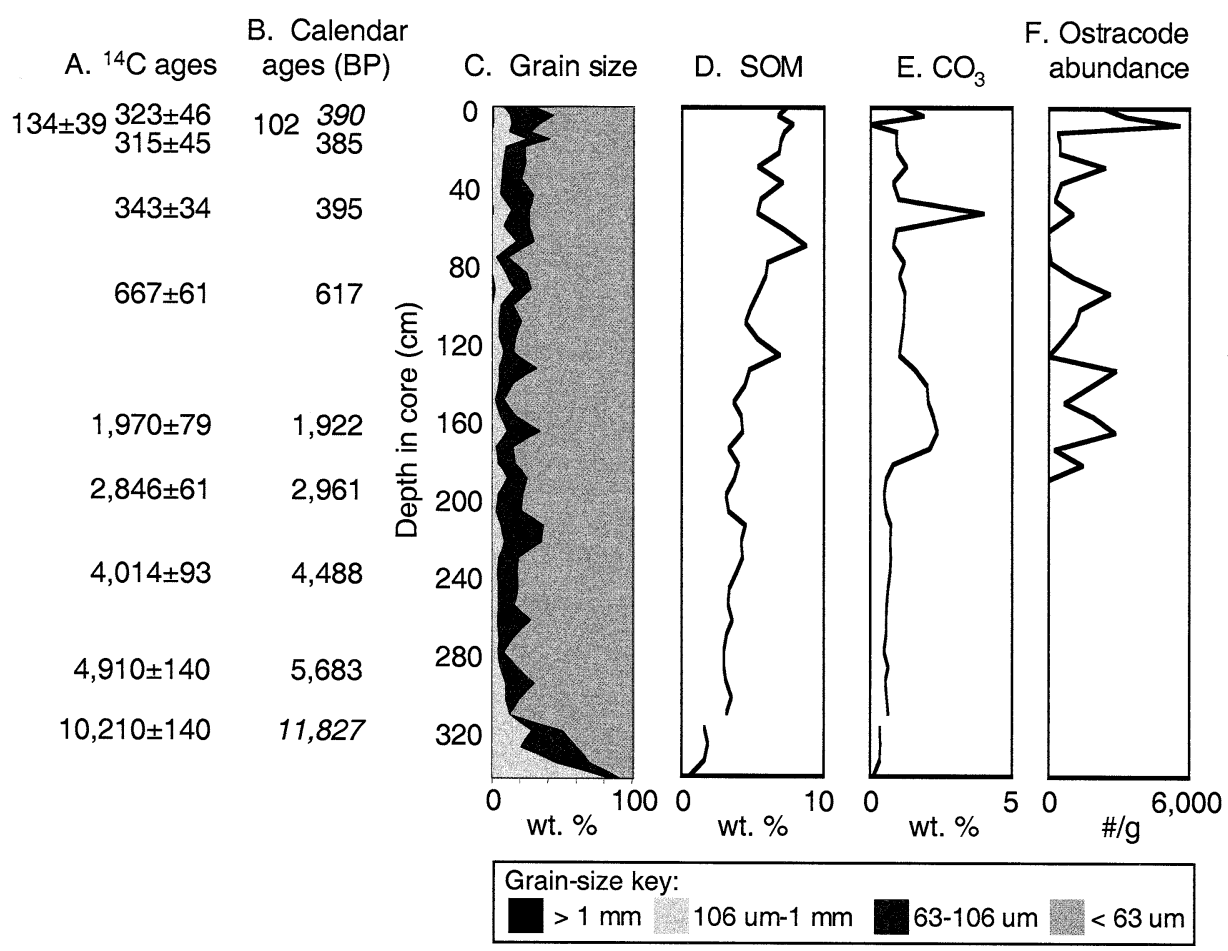

Fig. 4. Geochronology and sedimentology data for core LT-97-56V. (A) Radiocarbon ages. (B) Midpoint of $2 \sigma$ calendar-age range used for generating the age model. Dates in italics were excluded from the age-model calculation. (C) Grain-size distribution. (D) SOM concentration. (E) Sedimentary $\mathrm{CO}_{3}$ concentration. (F) Ostracode abundance in number of individuals per gram.

all depth-score values in that core to derive a lake-level deviation curve.

\section{Results}

\subsection{Geochronology and sedimentology}

Ten radiocarbon dates for core LT-97-56V indicate that sedimentation rates increased fairly constantly throughout the core, although the slope increased more steeply in the upper meter of the sediment core (Table 1, Figs. 2 and 4). The $\delta^{13} \mathrm{C}$ profile of core LT-97-56V closely resembles $\delta^{13} \mathrm{C}$ profiles in other cores with intact, ${ }^{210} \mathrm{~Pb}$ dated core tops collected from various sites in the lake, confirming the presence of core-top sediments in LT-97-56V (Alin, 2001; O'Reilly, 2001). Despite the appearance that two intervals of relatively constant sedimentation exist in core LT-
97-56V (Fig. 2A), the data were fit much better by a single polynomial than by separate linear regressions or polynomials for the two intervals (Fig. 2B).

Sediment MARs in the lower core ranged between 0.036 and $0.078 \mathrm{~g} \mathrm{~cm}^{-2} \mathrm{yr}^{-1}$ (average $0.053 \pm 0.011 \mathrm{~g} \mathrm{~cm}^{-2} \mathrm{yr}^{-1}$ for $103-302 \mathrm{~cm}$, $\sim 4000$ BC-1120 AD). In the upper core, sediment MARs increased to span a range from 0.082 to $0.207 \mathrm{~g} \mathrm{~cm}^{-2} \mathrm{yr}^{-1}$ (average $0.13 \pm 0.04$ for 0-103 cm, 1120-1997 AD). Linear sedimentation rates for LT-97-56V $\left(1.2 \pm 0.4 \mathrm{~mm} \mathrm{yr}^{-1}\right.$ for $0-103 \mathrm{~cm}, 0.4 \pm 0.1 \mathrm{~mm} \mathrm{yr}^{-1}$ for $103-302 \mathrm{~cm}$ ) indicate that sample resolution is on the order of 8 $10 \mathrm{yr} \mathrm{sample}^{-1}$ at $32-40$-yr intervals for the upper $20 \mathrm{~cm}$, with resolution stable but gaps increasing to $56-70 \mathrm{yr}$ from 20 to $103 \mathrm{~cm}$. Below $103 \mathrm{~cm}$, sample resolution drops to $25 \mathrm{yr}^{\text {sample }}{ }^{-1}$ spaced at $200-y r$ intervals.

Calibrated radiocarbon ages imply a deposi- 


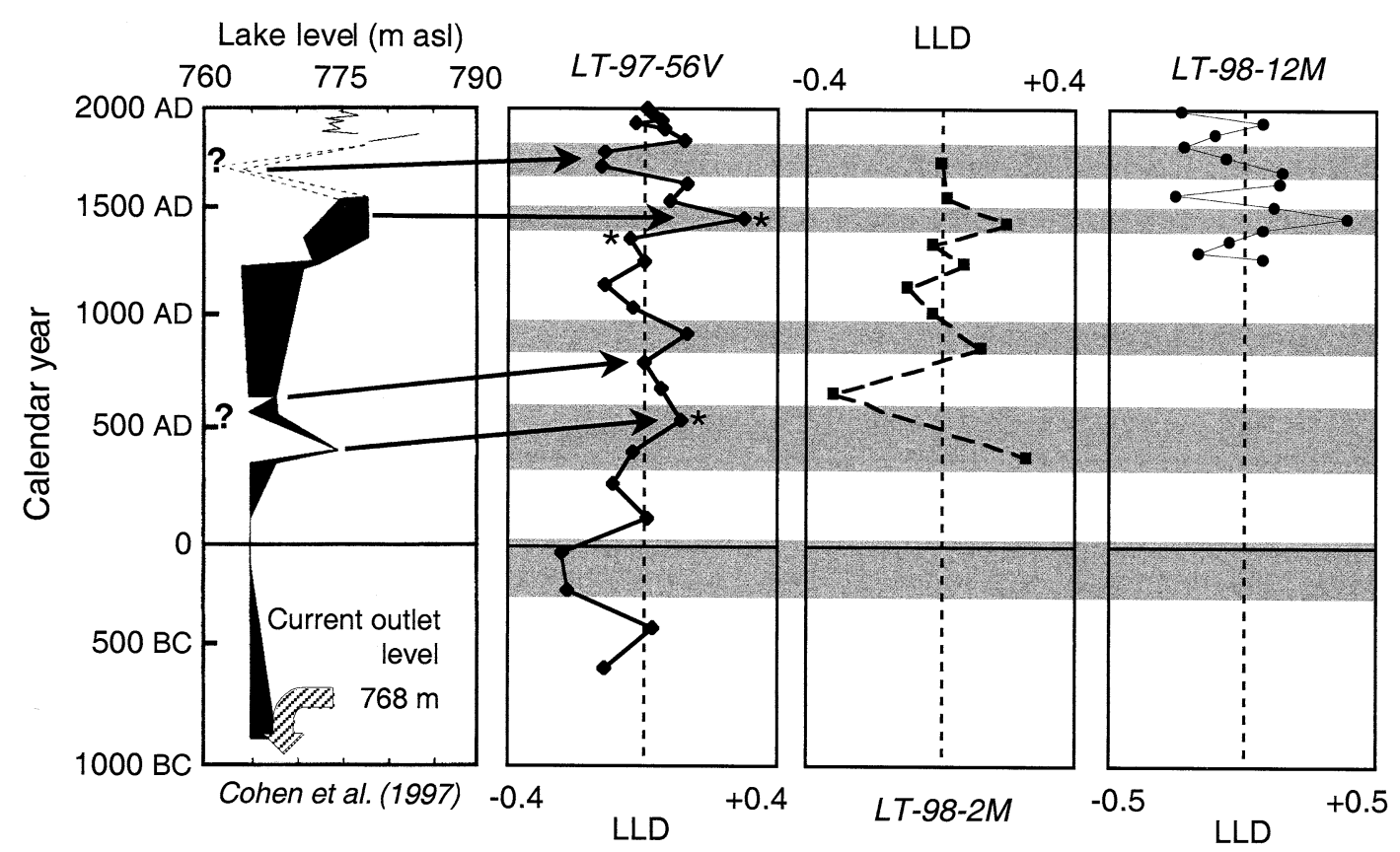

Fig. 5. Correspondence between the lake-level record of Cohen et al. (1997b) and ostracode-based water-depth reconstruction for cores LT-97-56V, LT-98-2M, and LT-98-12M for the past 2500 calendar years. Dashed lines in the Cohen et al. (1997b) lake-level curve indicate the interval during which the temporally unconstrained lowstand during the 16th-19th centuries occurred. Relative water-depth changes are plotted as lake-level deviations (LLD, in unitless depth-score values) for cores LT-97-56V, LT-982M, and LT-98-12M. Gray zones highlight prominent high- or lowstand features to facilitate comparison among cores. Asterisks on core LT-97-56V profile mark samples comprised of fewer than 500 ostracodes.

tional hiatus of $5000-6000 \mathrm{yr}$ near the base of core LT-97-56V, ending at $\sim 6400$ yr BP $(\sim 312$ $\mathrm{cm}$ depth) (Figs. 2B and 4B). Grain size fines sharply across the hiatus, from domination by very fine to medium sands below to silts above, indicating that the overlying sediments were deposited at substantially greater water depth (Fig. 4C). The reason for the hiatus is not apparent, but may represent erosion or an interval of nondeposition, as nearshore sedimentation in large lakes can be episodic.

Concurrent with the abrupt fining of sediment grain size at $312 \mathrm{~cm}$ and resumption of sediment deposition, concentrations of SOM and $\mathrm{CO}_{3}$ preserved in the sediment doubled, from $1.4 \pm 0.6 \%$ to $3.2 \pm 0.2 \% \mathrm{SOM}$ and from $0.3 \pm 0.1 \%$ to $0.6 \pm 0.04 \% \mathrm{CO}_{3}$, in the four samples on either side of the hiatus (Fig. 4D,E). SOM percentages continue to increase almost continuously upcore, with peaks in abundance at $126-127 \mathrm{~cm}(6.9 \%$, $\sim 580 \mathrm{AD})$ and $62-71 \mathrm{~cm}(7.2-8.7 \%, \sim 1390$
1500 AD). Carbonate concentrations increase to a broad peak of $2.1 \pm 0.1 \%$ from 140 to $175 \mathrm{~cm}$ (400 BC-325 AD), with an additional sharp peak in carbonate concentration $(4.2 \%)$ at $54-55 \mathrm{~cm}$ $(\sim 1580 \mathrm{yr}$ BP) representing a thin shell hash in the sediment (Fig. 4E).

\subsection{Paleoecology}

Ostracode remains were absent below $179 \mathrm{~cm}$ ( $\sim 500$ BC) (Fig. 4F). Above this core depth, ostracode abundance ranges from 7 to 5570 valves/ $\mathrm{g}$, with an average of 1360 valves/g. Three anomalously low values correspond to the peaks in SOM at $62-71 \mathrm{~cm}(\sim 1390-1500 \mathrm{AD})$ and 126 $127 \mathrm{~cm}$ ( 580 AD) (Fig. 4D-F). High SOM concentrations may explain intervals of low ostracode abundance, as organic acids and carbon dioxide generated by SOM degradation can lower porewater $\mathrm{pH}$ and dissolve sedimentary carbonates, including ostracode valves (Dean, 1999). 


\subsection{Relative water-depth reconstruction}

On a millennial timescale, the reconstructed relative lake-level curves for cores LT-97-56V, LT98-2M, and LT-98-12M show two prominent peaks roughly corresponding to lake highstands reported by Cohen et al. (1997b) to have occurred between $\sim 1250$ and $1550 \mathrm{AD}$ and at $430 \pm 110$ AD (Fig. 5). Based on the better-resolved chronology of core LT-97-56V compared to core LT$98-2 \mathrm{M}$ in this interval, we suggest that the first highstand in fact occurred at $580 \pm 70 \mathrm{AD}$, and both records place the latter highstand at $\sim 1500$ AD (LT-97-56V: $1495 \pm 45$ AD, LT-98$2 \mathrm{M}: 1470 \pm 55 \mathrm{AD})$. Lake level started to rise sometime between 1200 and $1300 \mathrm{AD}$, was interrupted by a brief decline in lake level at $1400 \pm 50$ $\mathrm{AD}$, and started to decline from peak levels shortly after 1500 AD. In addition, the lake-level curve delineates the timing of the previously described, but temporally unconstrained, lowstands from Cohen et al. (1997b). Core LT-97-56V indicates that the most significant lowstands in Lake Tanganyika's late Holocene history were centered around $200 \pm 90 \mathrm{BC}, 25 \pm 90 \mathrm{BC}, 290 \pm 75 \mathrm{AD}$, $440 \pm 75 \quad \mathrm{AD}, \quad 1090 \pm 50 \quad \mathrm{AD}, \quad 1200 \pm 50 \quad \mathrm{AD}$, $1730 \pm 35 \mathrm{AD}$, and $1800 \pm 30 \mathrm{AD}$ (Fig. 5). Other potentially important intervals of falling lake level occurred at $720 \pm 70 \mathrm{AD}, 850 \pm 65 \mathrm{AD}, 1400 \pm 50$ $\mathrm{AD}$, and $1580 \pm 45 \mathrm{AD}$.

At a more recent and highly resolved timescale, the reconstructed lake-level records from cores MIT-1 and LT-97-56V also correlate quite well with the recent historical record of lake-level change since $1846 \mathrm{AD}$ at Lake Tanganyika (lake-level data from Birkett et al., 1999; Evert, 1980) (Fig. 6). Two relative highstands reflected in the water-depth record from core LT-97-56V fall within the errors associated with the age model and sampling resolution of known highstands in the 1870s AD and 1960s AD. However, the lakelevel curve from core MIT-1 bears a striking resemblance to the instrumental lake-level record, beginning with a pronounced fall in both reconstructed and measured lake levels in the late 1800s. Thereafter, the MIT-1 record sensitively reflects meter-scale variations in lake level seen in the instrumental record in the 1910s, 1940s,

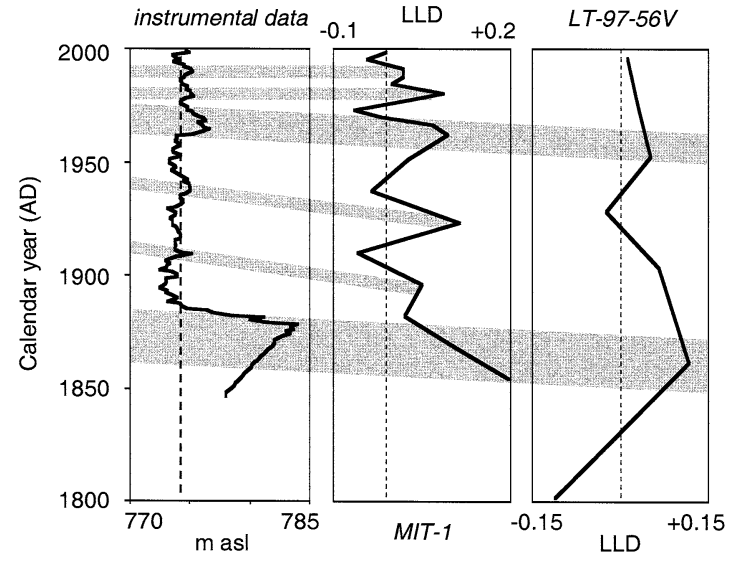

Fig. 6. Relationship between historical instrumental lake-level data since $1846 \mathrm{AD}$ and reconstructed water-depth values for cores LT-97-56V and MIT-1. Instrumental lake-level data are from Birkett et al. (1999) and Evert (1980). Dashed line in instrumental data plot represents mean lake level from 1900 to 1999 AD. Gray shading indicates proposed correlation zones between the cores and the instrumental record. Relative water-depth changes are plotted as lake-level deviations (LLD, in unitless depth-score values) for cores LT-97-56V and MIT-1.

1960s, late-1970s, and late-1980s, again within the range of errors associated with the core's age model. The sensitivity of this core record to reconstructing such fine-scale variations in water depth may be explained by the fact that it was collected in $15 \mathrm{~m}$ water depth, so small changes in water depth represent a greater proportional shift in depth than would be the case for the deepwater cores.

\section{Discussion}

\subsection{Robustness of ostracode-based water-depth reconstruction}

The ostracode-based lake-level curves presented here accurately reconstructed known past changes in lake level on timescales of decades to millennia. Mourguiart and Carbonel (1994; Mourguiart et al., 1998) experienced similar success in reconstructing paleolake levels at Lake Titicaca, based on a relatively large calibration data set of ostracode species distributions and ecological toleran- 
ces. As in Lake Tanganyika, many of the species Mourguiart and Carbonel $(1994,1998)$ relied on for their paleolake-level reconstructions had not yet been described taxonomically. These examples indicate that incomplete taxonomic or ecological knowledge of the system may not necessarily hinder the successful use of ostracode species-abundance data to generate paleolake-level reconstructions, provided that sufficient sampling of life assemblages and identification of specimens to stable taxonomic categories have occurred. Ostracode-based reconstruction of lake-level curves can potentially yield reliable, nearly continuous records of relative lake-level change when the sediment record is sampled at sufficiently high resolution and is anchored by a robust chronology.

However, all ostracode assemblages were located in ordination space at a substantial offset from their true depth. Despite this, the relative lake-level reconstructions based on them appeared to be reliable. We would expect some offset between water depths reconstructed in this manner using paleoecological assemblages and the actual water depths where living assemblages were collected for several reasons, and for this reason we have limited our discussion here to relative changes in water depth. First, post-mortem processes of spatial and temporal averaging render paleoecological ostracode assemblages as composites of living assemblages integrated over larger areas and through longer time intervals than the living assemblages used for the calibration data set (Alin, 2001; Park et al., 2003). Therefore, the paleoecological assemblages may comprise individuals from species typically inhabiting a somewhat greater variety of substrate types and depths than the muddy and silty sediments from which cores are collected. Alin (2001) has shown that paleoecological assemblages in shallow water are offset in ordination space from living assemblages because of substrate differences. In general, the cores were also collected in somewhat deeper water than the majority of living assemblages. Second, the duration of a highstand (or lowstand) may affect the reconstructed depth score for that interval. Because ostracode assemblages represent time-averaged composites, a brief highstand may be more weakly registered in the paleoecological record than another highstand of comparable magnitude but longer duration, as the ostracode assemblage representing the longer highstand will have a greater proportion of individuals from deepwater species. The sedimentation rate will also affect the extent of time averaging and thus apparent relative water-depth changes. Third, substantial variability in the species-assemblage data may be attributable to the remaining significant environmental factors in CCA Axis 2 vs. Axis 3 space: latitude and watershed disturbance level. The significance of latitude and longitude as 'environmental' variables reflects the degree of highly localized ostracode endemism within the lake. Species composition of assemblages changes substantially along the lakeshore, which should affect the absolute values of depth scores among sites. Anthropogenic watershed disturbance may also overprint the signal of lake-level change in paleoecological ostracode assemblages. For the purposes of this paper, we have included only species-assemblage data collected offshore from minimally disturbed watersheds, to eliminate the confounding signal of changing watershed disturbance levels through time on our paleolake-level reconstruction. The three longer-term lake-level records presented here also come from a limited stretch of the lakeshore, reducing the influence of species endemism on the comparison. Finally, because the ostracode-based method of inferring past water depth does not accurately reconstruct true lake level, it is preferable to use this method to refine the timing of relative changes and use other physical evidence (e.g. winnowed shell lags, depth distribution of former beachrocks and stromatolites) to constrain the realized magnitude of the lake-level change.

A further factor which may influence the quality of the ostracode paleoecological record is the abundance of SOM in the sediment interval. As discussed previously, high concentrations of SOM can dissolve ostracode valves, potentially biasing the remaining ostracode assemblage. Three core samples with high SOM also had low ostracode valve abundances (asterisks in LT-97-56V profile in Fig. 5). However, we suggest that the simultaneous peaks in SOM and lake level and the corresponding nadirs in ostracode abundance may be 
explained by covariation in water depth and SOM preservation, with ramifications for ostracode preservation. Verschuren (2001) showed that SOM and water depth covary significantly in a small, shallow-lake setting. Johnson and Ng'ang'a (1990) demonstrated that this relationship does not pertain to deepwater milieus of large lakes. We suggest that in shallow-water environments within large lakes (i.e. $<100 \mathrm{~m}$ ), the positive correlation between water depth and organic-matter preservation may still be valid because the decreased intensity of winnowing with increasing depths will allow greater accumulation of SOM (cf. Verschuren, 2001).

\subsection{Late Holocene lake-level variation at Lake Tanganyika}

The lake-level curves reconstructed here based on ostracode species-abundance data indicate more substantial variation in lake level than previously reported during the past 2500 years (Figs. 5 and 6). These lake-level reconstructions accurately replicated known lake-level changes in instrumental data since $\sim 1850$ AD (Birkett et al., 1999; Evert, 1980) and in stromatolitic and stable isotopic records dating to $\sim 1000 \mathrm{BC}$ (Cohen et al., 1997b). This is true despite the fact that not all ostracode species in core samples were represented in the live calibration database and that the depth range of samples in the live database lies dominantly above the water depth of the cores examined here. In particular, the lake-level curves reported here substantiate the late Holocene $(\sim 1250-1550$ AD, $430 \pm 110$ AD) highstands reported by Cohen et al. (1997b), although these new data refine the timing of the maximum highstands to $580 \pm 70 \mathrm{AD}$ and $1495 \pm 45 \mathrm{AD}$. All dates discussed here are from core LT-97-56V because of its higher sedimentation rate and resolution, although dates from core LT-98-2M are within 10-25 years of dates from LT-97-56V for all events in the period 1000-1600 AD. Lake level appears to have begun rising sometime in the 13th century toward this maximum at $\sim 1500 \mathrm{AD}$, with a brief reversal of this rising trend at $\sim 1400$ AD. In addition, the late 16th-early 19 th century lowstand discussed by Cohen et al. (1997b) appears to represent recurrent or persistent drought conditions between $\sim 1550$ and 1850 $\mathrm{AD}$, resulting in lake lowstands or rapid declines in lake level at $1580 \pm 15 \mathrm{AD}, 1730 \pm 35 \mathrm{AD}$, and $1800 \pm 30 \mathrm{AD}$ (Fig. 5). Other significant intervals of low lake levels occurred at $200 \pm 90 \mathrm{BC}, 25 \pm 90$ $\mathrm{BC}, 290 \pm 75 \mathrm{AD}, 440 \pm 75 \mathrm{AD}, 1090 \pm 50 \mathrm{AD}$, $1200 \pm 50 \mathrm{AD}$, and lake levels fell during the interval(s) $720 \pm 60 \mathrm{AD}$ and $850 \pm 65 \mathrm{AD}$. These results are consistent with the observation that lake levels were generally lower than the lake outlet level for most of the past 2500 years (Cohen et al., 1997b).

Based on the timing of lake-level increases and declines, it appears that Lake Tanganyika was relatively low through the latter part of the Medieval Warm Period (MWP; 1050-1250 AD), rising or high during the first half of the Little Ice Age (LIA; 1250-1550 AD), and reflecting dominantly arid conditions throughout the lake basin during the latter half of the LIA $(\sim 1550-1850$ AD). Charcoal-abundance data from Cohen et al. (1999) further corroborate the occurrence of severe droughts and increased fire frequency in the Lake Tanganyika basin between $\sim 1550$ and 1850 AD (Alin, 2001; Cohen et al., 1999). Charcoal abundance increased earlier (starting at $\sim 1200$ AD) than indications of lake-level decline in core LT-98-2M, indicating that the onset of drought may have begun as early as the 13th century AD in the central basin of Lake Tanganyika (Cohen et al., 1999). The time lag between this early terrestrial indicator of drought in the central basin and the drop in lake level reflected by ostracode assemblages may be explained by the observation that the highlands in the northern basin of the lake (in Burundi and the Democratic Republic of Congo) serve as the major source of runoff to the lake and may not have been affected by the increasing regional aridity as early as the lower elevation forests of the central basin (Cohen et al., 1997b). A stronger pulse in sedimentary charcoal influx occurred simultaneously with indications of lowered lake levels from the mid1500s AD to 1790 AD (core top) (Cohen et al., 1999). Peak carbonate abundance corresponding to the shelly hash layer at $\sim 54-55 \mathrm{~cm}$ also coincided temporally with the onset of the 1550 
1850 AD droughts (shell hash age $1580 \pm 15$ AD). The presence of shell hash in water of this depth indicates that lake level was $>30 \mathrm{~m}$ lower than modern lake-surface elevation during deposition and further substantiates the ostracode-reconstructed drop in lake level at $1580 \pm 15$ AD. Together, these results suggest that regional aridification began in the $1200 \mathrm{~s}$ AD, increasing in extent and diminishing the source of runoff from the northern highlands by the mid-1500s AD, such that lake level experienced a substantial decline at that time.

The aridification during the LIA comes in the context of a longer-term regional aridification in East Africa reported by many authors to have occurred during the last $1500-5500$ years (e.g. Beuning et al., 1997; Russell et al., 2003; Stager and Johnson, 2000; Vincens, 1993). Cohen et al. (1997b) demonstrate that Lake Tanganyika spent much of the late Holocene as a closed basin, with water levels just below the modern outlet elevation (768 $\mathrm{m}$ asl). In the central Lake Tanganyika basin, the pollen record from core LT-98-2M shows substantial decreases in arboreal pollen from $\sim 20-30 \%$ representation starting at $\sim 400$ $\mathrm{BC}$ and declining to $<10 \%$ after a second drop at around 500 AD (Cohen et al., 1999). Thus, the late Holocene history of Lake Tanganyika appears to have been one of relatively low lake level punctuated by relatively short-lived episodes of wetter conditions.

\subsection{Agreement with other records of moisture balance in Africa}

The new information on the timing of lowstands presented here is fairly coherent with other climate records from East Africa during some time intervals, less so at other times. This is consistent with the great variability in coherency among climate records at various timescales in this region (Nicholson, 1996, 2000). In the earliest part of the record, the most pronounced lowstand reflected in the lake-level curve from core LT-97$56 \mathrm{~V}(\sim 200-25 \mathrm{BC})$ coincides with the maximum late Holocene lowstand seen at Lake Edward at $\sim 2000$ yr BP (Russell et al., 2003) (Fig. 7). Directly to the north of Lake Tanganyika, Lake

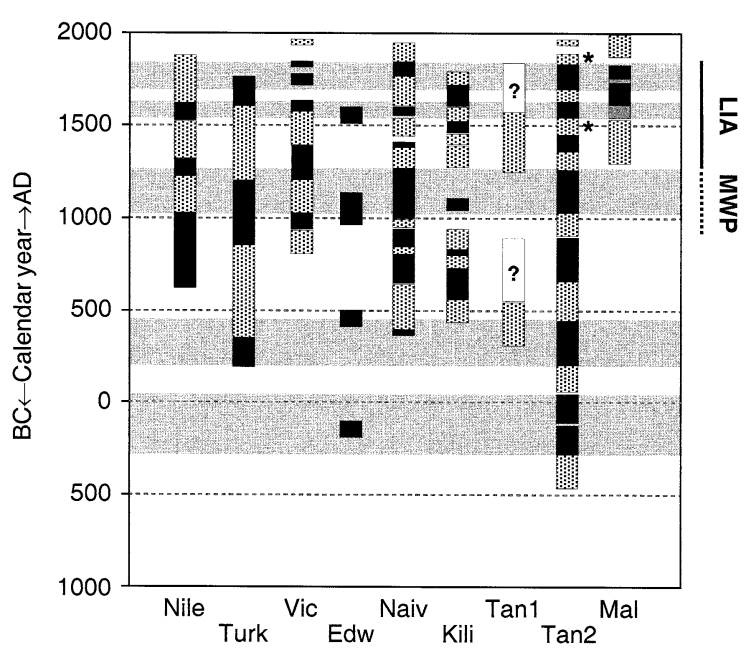

Fig. 7. Paleoclimatic records of relative moisture balance from various locales in East Africa. Records are arranged in latitudinal order from north to south. Codes stand for: Nile, Nile River summer flows (Herring, 1979); Turk, Lake Turkana (Verschuren, in press); Vic, Lake Victoria (Nicholson, 1998); Edw, Lake Edward (Russell et al., in press); Naiv, Lake Naivasha (Verschuren, 2001; Verschuren et al., 2000); Kili, Mount Kilimanjaro (ice-core record: Gasse, 2002; Thompson et al., 2002); Tan1, Lake Tanganyika (stromatolite record of Cohen et al., 1997b); Tan2, Lake Tanganyika (ostracode-based record of this paper); and Mal, Lake Malawi (Johnson et al., 2001, 2002). Black and gray vertical bars indicate periods of severe and less severe drought conditions, respectively, and/or highest (and high) diatom productivity for Lake Malawi. Solid white vertical bars with question marks denote lowstands with poor age control. Stippled white vertical bars represent periods of positive moisture balance, lake highstands, low diatom productivity, etc. Horizontal gray zones represent approximate periods of lake-level lowstands in Lake Tanganyika, to facilitate comparison of timing among records. Typical timing assigned to the MWP $(\sim 900-1250 \mathrm{AD})$ and the LIA $(\sim 1250-1850$ AD) is indicated in the upper right of the graph.

Kivu experienced a prolonged lowstand, resulting in lake basin closure, between $\sim 3700$ and $1400 \mathrm{yr}$ $\mathrm{BP}$, although the resolution of the lake-level record at Kivu is insufficient to compare the period of maximum aridity at Lake Kivu directly with the timing of the maximum lowstand at Tanganyika (Haberyan and Hecky, 1987). During this early part of the Lake Tanganyika record, no other regional records of sufficient resolution are available for comparison.

More regional records of moisture balance are available for comparison for much of the first 
millennium AD (Fig. 7). During the interval 200-500 AD (290 \pm 75 AD, $440 \pm 75$ AD), Tanganyika again experienced relative lowstands. This contrasts with the stromatolite record of Cohen et al. (1997b), but as previously discussed, we suggest that their $430 \pm 110$ AD highstand occurred later $(580 \pm 70 \mathrm{AD})$. Within the same window of time, lakes Turkana and Edward experienced lowstands, although of shorter duration than that at Tanganyika (Russell et al., in press; Verschuren et al., 2000). The late 6th century highstand at Tanganyika is paralleled by a highstand at Lake Turkana and matches within the range of age-model errors with wet conditions on Mount Kilimanjaro (Verschuren, in press; Thompson et al., 2002). The $\delta^{18} \mathrm{O}$ of ice in cores collected from glaciers atop Kilimanjaro registers depleted signatures during approximately this interval (Thompson et al., 2002). Although Thompson et al. (2002) interpret this record as a proxy for temperature, $\delta^{18} \mathrm{O}$ records in the tropics are more frequently interpreted to represent the precipitation 'amount' effect and may therefore comprise a rainfall rather than a temperature signal (Gasse, 2002). The Kilimanjaro $\delta^{18} \mathrm{O}$ record bears a striking resemblance to the lake-level curve for nearby Lake Naivasha, supporting the interpretation that times of depleted $\delta^{18} \mathrm{O}$ correspond to wetter, rather than colder, intervals (Thompson et al., 2002; Verschuren, 2001; Verschuren et al., 2000). Thus, the Kilimanjaro ice-core record bears $\delta^{18} \mathrm{O}$ signatures consistent with increased precipitation in the region coeval with the Tanganyika $\sim 500 \mathrm{AD}$ highstand. The timing of the following lowstand at Lake Tanganyika is suggested here to fall in the interval $\sim 700-850$ $\mathrm{AD}$, and Kilimanjaro appears to be relatively dry during this interval (Thompson et al., 2002). Lake Tanganyika ended the first millennium with a relative highstand at $\sim 950-1000 \mathrm{AD}$, which may correspond to a return of wetter conditions on Kilimanjaro (Thompson et al., 2002). Although certain features of the lake-level record for Tanganyika appear to overlap with other regional indicators of moisture balance, these apparent connections are not yet sufficiently resolved chronologically to convince us of their temporal coincidence. Until higher-resolution rec- ords are available for more locales during the first millennium $\mathrm{AD}$, it will not be possible to ascertain to what degree moisture-balance changes are coherent among regions within East Africa.

At the beginning of the second millennium AD, lake level at Lake Tanganyika fell and remained relatively low during $\sim 1050-1250 \mathrm{AD}$, which corresponds to the timing of the MWP in many locales, albeit with a later onset than in some areas (Fig. 7). Lakes Turkana, Edward, and Naivasha all experienced pronounced and/or prolonged lowstands during this period (Russell et al., in press; Verschuren, 2001, in press; Verschuren et al., 2000). Mt. Kilimanjaro's $\delta^{18} \mathrm{O}$ record shows some of its most enriched values during the past 1500 years from $\sim 1040$ to $1100 \mathrm{AD}$, suggesting diminished rainfall in equatorial East Africa (Thompson et al., 2002). Nicholson (1998) collated information on severe droughts and famines in East Africa based on oral histories and Nile flow records to infer changes in the level of Lake Victoria prior to historical data. Nile River waters at their lowest annual flow levels (MayJune), measured at the Rodah Nilometer in Egypt, are dominantly comprised of runoff from equatorial rainfall in the Lake Victoria region (Herring, 1979). Thus, the Nile flow and Lake Victoria records discussed here are not entirely independent, although the Lake Victoria record comprises historical data on droughts and famines from oral traditions as well. In contrast with the preceding observations, Nile flow records and oral traditions suggest that rainfall in the Lake Victoria watershed, directly west of Lake Naivasha, was relatively high (Herring, 1979; Nicholson, 1998). With the exception of Lake Victoria, a reasonably coherent picture thus unfolds of the MWP in East Africa being a relatively arid period, although a more direct and highly resolved record of moisture balance conditions from the Lake Victoria basin will be necessary to resolve this issue.

During the first half of the LIA $(\sim 1250-1550$ AD), East Africa generally experienced a wetter climate. Lake Tanganyika experienced its maximum highstand at $\sim 1450-1550 \mathrm{AD}$, according to ostracode water-depth reconstructions. The 
rise in lake level leading to this highstand started sometime in the 13th century $\mathrm{AD}$, reaching a relative peak reflected in all three ostracode lakelevel records at $\sim 1300 \mathrm{AD}$, followed by a brief decline at $\sim 1400 \mathrm{AD}$, and culminating in a maximum highstand at $\sim 1500 \mathrm{AD}$ (Fig. 5). This maximum highstand is coincident with one of two LIA peak periods of cooling in the sea surface temperatures (SSTs) off the west coast of Africa and in the Northern Hemisphere (deMenocal et al., 2000). During the early LIA, lakes Turkana, Victoria, and Naivasha had high lake levels, and Naivasha also experienced an arid interval at $\sim 1400$ AD (Nicholson, 1998; Verschuren, in press; Verschuren et al., 2000). The centennialaverage flow conditions in the Nile were higher than average through this time (Herring, 1979), and $\delta^{18} \mathrm{O}$ values in the Kilimanjaro ice core were again depleted, consistent with higher rainfall in East Africa (Gasse, 2002; Thompson et al., 2002). Biogenic silica concentrations in sediment cores, which are used as an indicator of paleoproductivity levels, were relatively low in the north basin of Lake Malawi during the first half of the LIA (Johnson et al., 2001, 2002). Johnson et al. (2002) interpret times of high productivity to reflect northerly winds driving upwelling in the north basin, which in turn would suggest a southward incursion of the ITCZ, although it has also been suggested that the periods of higher productivity coincided with lowered lake levels at Lake Malawi. Low productivity in Lake Malawi's north basin during the early LIA may therefore be consistent with the interpretation of relatively high lake levels and the southerly winds that are dominant there today. Thus, all available indicators suggest that the early LIA in East Africa had a positive moisture balance.

In contrast, the second half of the LIA ( 1550-1850 AD) was a period marked by recurrent or persistent drought conditions in many parts of East Africa. Tanganyika saw significant declines or lowstands in lake level in the intervals $1580 \pm 15 \mathrm{AD}, 1730 \pm 35 \mathrm{AD}$, and $1800 \pm 30 \mathrm{AD}$ (Fig. 5). Nicholson (1998) reports severe droughts and famines during the 1580s $\mathrm{AD}$ and several during the $1720 \mathrm{~s}-1760 \mathrm{~s}$ AD in the Lake Victoria region, in addition to a period of continental arid- ity during the 1820 s -1830 s AD. Low Nile flows also characterize the period of the $1580 \mathrm{~s}-1620 \mathrm{~s}$ $\mathrm{AD}$, while high Nile flows dominated between 1360 and 1530 AD (Herring, 1979; Nicholson, 1998). Two arid intervals in the Lake Naivasha record overlap substantially with the three 1550 1850 AD Tanganyika lowstands (Verschuren et al., 2000: 1560-1620 AD, 1760-1840 AD). Lower lake levels in Turkana and Edward are consistent with the picture of regional drought during the late LIA (Russell et al., in press; Verschuren, in press). Kilimanjaro oxygen isotope values also experience periods of relative enrichment during this time (Thompson et al., 2002). Finally, high productivity in the north of Lake Malawi suggests northerly winds (i.e. a more southerly ITCZ) and/or lower lake level in the basin (Johnson et al., 2001, 2002). Interestingly, a high-resolution record of bulk titanium (Ti) content in a Cariaco Basin (north of Venezuela) sediment core reveals general LIA aridity, with peak aridity at $\sim 1590$ AD, 1670-1690 AD, and 1750-1780 AD, matching the timing of East African droughts fairly closely (Haug et al., 2001). Sedimentary Ti content reflects rainfall over northern South America, with arid intervals interpreted to reflect southward migration of the ITCZ (Haug et al., 2001). Thus, the latter half of the LIA appears to be characterized by recurrent, pronounced droughts throughout East Africa, with teleconnections to other tropical regions, which may be related to a shift in ITCZ location.

Since the termination of the LIA, many sites in East Africa have instrumental records of rainfall and/or lake level, making it possible to assign accurate elevations to lake-surface levels. At Lake Tanganyika, a highstand of $784 \mathrm{~m}$ asl occurred in $1878 \mathrm{AD}$ (Evert, 1980), and this is reflected in the lake-level curves of cores LT-97-56V and MIT-1. This peak is contemporaneous with the second cooling peak in the West African SST record discussed by deMenocal et al. (2000), and also coincides with high lake levels in lakes Naivasha and possibly Malawi (Johnson et al., 2001; Verschuren, 2001). The ostracode record of core MIT-1, and possibly that of core LT-97-56V, also reflects the increase in lake level resulting from intense rainfall during 1961-1962 AD. 


\section{Conclusions}

The broad congruence between previously published and new lake-level data presented here for Lake Tanganyika indicates that paleoecological ostracode assemblages can provide reliable and sensitive reconstructions of past changes in lake level. En masse, an ostracode assemblage reflects the relative water depth of its habitat, in addition to the influence of other environmental factors. These other factors make it impossible to quantitatively reconstruct lake-level changes, but when used in tandem with available physical evidence of lake highstand or lowstand levels, it should be possible to assess both the timing and magnitude of past lake-level fluctuations.

The ostracode-based lake-level reconstruction presented here contributes more highly resolved information on the timing and direction of lakelevel fluctuations in Lake Tanganyika for the past 2500 years. In general, the late Holocene climate history of Lake Tanganyika is characterized by aridity, punctuated by brief intervals of higher rainfall. The ostracode water-depth record refines the timing of known but undated lowstands of $-15-40 \mathrm{~m}$ in the late Holocene to $580 \pm 70 \mathrm{AD}$ and recurrent droughts during the second half of the LIA $(1580 \pm 15 \mathrm{AD}, 1730 \pm 35 \mathrm{AD}$, and $1800 \pm 30$ AD). The MWP also appears to have been arid at Lake Tanganyika $(\sim 1050$ $1250 \mathrm{AD}$ ), although the intervening early part of the LIA was characterized by higher lake levels that may have been sustained longer than any other highstand in this record (rising nearly continuously from $\sim 1250$ AD to a peak at $\sim 1500$ AD). Other occasions of marked aridity not resolved in previous records at Lake Tanganyika include the periods $\sim 200-0 \mathrm{BC}$, $\sim 200-500$ AD, and $\sim 700-850$ AD. Records of MWP and late LIA aridity and early LIA wetness are reasonably coherent throughout East Africa. The sparsity of earlier paleoclimate records in East Africa makes it impossible at this juncture to ascertain whether lake levels fluctuated in synchrony in response to decade-century scale climate changes in the preceding centuries.

\section{Acknowledgements}

We are grateful to the National Science Foundation (Grants EAR-9627766 and ATM-9619458 to A.S.C., and a Graduate Research Fellowship to S.R.A.), the UN/GEF Lake Tanganyika Biodiversity Project, and the University of Arizona (small grants and a fellowship to S.R.A.) for funding and logistical assistance. We thank the Tanzanian Commission for Science and Technology and the Tanzanian Immigration Agency for the permits necessary for conducting this research. The assistance of the crew of the R/V Explorer, C. Scholz, J. McGill, P. Cattaneo, and numerous others was essential and greatly appreciated in collecting the cores. In addition, we thank D.L. Dettman and O.K. Davis for assistance with radiocarbon dating and identification of radiocarbon samples, respectively; C. Birkett at NASA for lake-level data from satellite altimetry; J.S. Alin and G.W. Holtgrieve for assistance with data analyses; T.C. Johnson, J.M. Russell, J.T. Overpeck, K.W. Flessa, P.N. Reinthal, R. Robichaux, and C.M. O'Reilly for helpful discussions and/or comments on earlier versions of the manuscript; and K. Martens and P. Mourguiart for constructive reviews. This is International Decade of East African Lakes (IDEAL) contribution number 147.

\section{Appendix 1}

List of species included in the live ostracode database for CCA. Undescribed species are given a numerical moniker and refer to specimens in the reference collection at the University of Arizona ${ }^{1}$.

\footnotetext{
1 The numbers of undescribed species in the University of Arizona ostracode reference collection do not necessarily reflect the overall diversity of undescribed species in their respective genera. When numbered species are identified as either a described species or lumped with another numbered species, their numbers are not recycled in order to avoid future taxonomic confusion. Thus, the species numbers suggest artificially high numbers of undescribed taxa in various Tanganyikan ostracode genera.
} 


\section{SUPERFAMILY CYTHEROIDEA}

Family Cytherideidae

Archaeocyprideis tuberculata ${ }^{2,3}$

Archaeocyprideis n.sp. $2^{3}$

Archaeocyprideis n.sp. $10^{3}$

Archaeocyprideis n.sp. 15

Cyprideis loricata ${ }^{2}$

Cyprideis mastai ${ }^{3}$

Cyprideis profunda $a^{2,3}$

Cyprideis rumongensis

Cyprideis spatula ${ }^{3}$

Cyprideis torosa

Cyprideis n.sp. 20

Cyprideis n.sp. 23

Cyprideis n.sp. $24^{3}$

Kavalacythereis braconensis ${ }^{3}$

Mesocyprideis irsacae ${ }^{3}$

Mesocyprideis nitida ${ }^{3}$

Mesocyprideis pila ${ }^{3}$

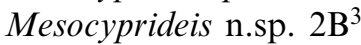

Mesocyprideis n.sp. $9^{3}$

Romecytheridea ampla ${ }^{3}$

Romecytheridea longior ${ }^{2,3}$

\footnotetext{
${ }^{2}$ Species that were published under other names in Alin et al. (1999) or Wells et al. (1999) have the following synonomies (old name $=$ new name), based largely on subsequent formal descriptions of these taxa in Park and Martens (2001) and Wouters and Martens (1999, 2001): Cytheroidea - Archaeocyprideis sp. 1=Archaeocyprideis tuberculata, Cyprideis n.sp. $1=$ Tanganyikacythere n.sp. 1, Cyprideis sp. $3=$ Cyprideis profunda, Gomphocythere n.sp. = Gomphocythere coheni, Gomphocythere sp. 3=Gomphocythere downingi, Gomphocythere sp. $13=$ Gomphocythere wilsoni, Gomphocythere sp. 16= Gomphocythere woutersi, Gomphocythere $\mathrm{sp} . \mathrm{y}=$ Gomphocythere wilsoni, Gomphocythere sp. $\mathrm{z}=$ Gomphocythere downingi, Mesocyprideis sp. 2A = Cyprideis loricata, and Romecytheridea n.sp. $13=$ Romecytheridea longior. Cypridoidea - Allocypria claviformis group = Allocypria mucronata .
}

${ }^{3}$ Species that also occurred in core LT97-56V. Additional species that occurred in core LT97-56V but not in the live database: Cytheroidea - Gomphocythere n.sp. 11, Kavalacythereis hystrix, Mesocyprideis n.sp. 4, Tanganyikacythere n.sp. 18. Cypridoidea - Allocypria claviformis, Allocypria humilis, Allocypria cf. inclinata, Allocypria n.sp. 20, Candonopsis n.sp. 15, Cypridopsis n.sp. 'fivespur', Cypridopsis n.sp. 21, Cypridopsis n.sp. 25, Mecynocypria obtusa, Mecynocypria parvula, Mecynocypria $\mathrm{n} . \mathrm{sp} .21$, Mecynocypria $\mathrm{n}$.sp. 33, Mecynocypria $\mathrm{n} . \mathrm{sp}$. 36, Mecynocypria n.sp. 37, Mecynocypria n.sp. 40, and Tanganyikacypridopsis n.sp. 1.
Romecytheridea tenuisculpta ${ }^{3}$

Romecytheridea n.sp. 10

Romecytheridea n.sp. 14

Romecytheridea n.sp. 15

Romecytheridea n.sp. 18

Tanganyikacythere burtonensis ${ }^{3}$

Tanganyikacythere caljoni ${ }^{3}$

Tanganyikacythere $\mathrm{n} . \mathrm{sp} .1^{2}$

Tanganyikacythere n.sp. 16

Tanganyikacythere n.sp. 18

Family Limnocytheridae

Gomphocythere alata ${ }^{3}$

Gomphocythere coheni ${ }^{2,3}$

Gomphocythere cristata ${ }^{3}$

Gomphocythere curta ${ }^{3}$

Gomphocythere downingi $i^{2,3}$

Gomphocythere wilsoni ${ }^{2,3}$

Gomphocythere woutersi ${ }^{2,3}$

Gomphocythere n.sp. 18

Limnocythere n.sp. $8^{3}$

Family Cytheridae

cf. Elpidium n.sp. 1

SUPERFAMILY CYPRIDOIDEA

Family Cyclocyprididae

Allocypria aberrans

Allocypria humilis $^{3}$

Allocypria mucronata ${ }^{2,3}$

Allocypria n.sp. $5^{3}$

Allocypria n.sp. $11^{3}$

Allocypria n.sp. 17

Allocypria n.sp. 18

Mecynocypria complanata

Mecynocypria conoidea ${ }^{3}$

Mecynocypria declivis

Mecynocypria deflexa

Mecynocypria emaciata ${ }^{3}$

Mecynocypria opaca ${ }^{3}$

Mecynocypria subangulata

Mecynocypria n.sp. 8

Mecynocypria n.sp. $9^{3}$

Mecynocypria n.sp. 13

Mecynocypria n.sp. 14

Mecynocypria n.sp. 17

Mecynocypria n.sp. $20^{3}$

Mecynocypria n.sp. 22

Mecynocypria n.sp. $29^{3}$ (opaca group)

Mecynocypria n.sp. $30^{3}$ 
Family Candoniidae

Candonopsis depressa ${ }^{3}$

Candonopsis n.sp. $2^{3}$

Candonopsis n.sp. $7^{3}$

Candonopsis n.sp. $8^{3}$

Candonopsis n.sp. 9

Family Cyprididae

Cypridopsis bidentata

Cypridopsis lacustris ${ }^{3}$

Cypridopsis obliquata

Cypridopsis serrata ${ }^{3}$

Cypridopsis n.sp. 5

Cypridopsis n.sp. $6^{3}$ (species group)

Cypridopsis n.sp. 8

Cypridopsis n.sp. 13

Cypridopsis n.sp. $15^{3}$

Cypridopsis n.sp. $18^{3}$

Cypridopsis n.sp. $22^{3}$

Cypridopsis n.sp. $23^{3}$

Tanganyikacypridopsis acanthodes

Tanganyikacypridopsis calcarata ${ }^{3}$

Tanganyikacypridopsis depressa ${ }^{3}$

Tanganyikacypridopsis n.sp. $3^{3}$

Tanganyikacypridopsis n.sp. 4

Tanganyikacypridopsis n.sp. 5

Tanganyikacypridopsis n.sp. $8^{3}$

Tanganyikacypris matthesi

Tanganyikacypris stappersi

Tanganyikacypris n.sp. $1^{3}$

Cypridid indet. 2

\section{SUPERFAMILY DARWINULOIDEA}

Family Darwinulidae

Darwinula stevensoni ${ }^{3}$

\section{References}

Alin, S.R., 2001. Calibration and interpretation of Holocene paleoecological records of diversity from Lake Tanganyika, East Africa. Ph.D. Thesis, University of Arizona, Tucson, AZ, 234 pp.

Alin, S.R., Cohen, A.S., Bills, R., Gashagaza, M.M., Michel, E., Tiercelin, J.-J., Martens, K., Coveliers, P., Mboko, S.K., West, K., Soreghan, M., Kimbadi, S., Ntakimazi, G., 1999. Effects of landscape disturbance on animal communities in Lake Tanganyika, East Africa. Conserv. Biol. 13, 10171033.

Alin, S.R., O'Reilly, C.M., Cohen, A.S., Dettman, D.L., Palacios-Fest, M.R., McKee, B.A., 2002. Effects of land-use change on aquatic biodiversity: a view from the paleorecord at Lake Tanganyika, East Africa. Geology 12, 1143-1146.

Bengtsson, L., Enell, M., 1986. Chemical analysis. In: Berglund, B.E. (Ed.), Handbook of Holocene Palaeoecology and Palaeohydrology. Wiley, Chichester, pp. 423-450.

Beuning, K.R.M., Talbot, M.R., Kelts, K., 1997. A revised 30,000-year paleoclimatic and paleohydrologic history of Lake Albert, East Africa. Palaeogeogr. Palaeoclimatol. Palaeoecol. 136, 259-279.

Birkett, C., Murtugudde, R., Allan, T., 1999. Indian Ocean climate event brings floods to East Africa's lakes and the Sudd Marsh. Geophys. Res. Lett. 26, 1031-1034.

Cohen, A.S., Lezzar, K.-E., Tiercelin, J.-J., Soreghan, M., 1997a. New palaeogeographic and lake-level reconstructions of Lake Tanganyika: implications for tectonic, climatic, and biological evolution in a rift lake. Basin Res. 9, 107-132.

Cohen, A.S., Palacios-Fest, M.R., Dettman, D., Msaky, E., Livingstone, D., McKee, B., 1999. Lake Tanganyika Biodiversity Project Special Study on Sediment Discharge and its Consequences: Paleolimnological Investigations. Lake Tanganyika Biodiversity Project. Natural Resources Institute, Kent, 165 pp.

Cohen, A.S., Talbot, M.R., Awramik, S.M., Dettman, D.L., Abell, P., 1997b. Lake level and paleoenvironmental history of Lake Tanganyika, Africa, as inferred from late Holocene and modern stromatolites. Geol. Soc. Am. Bull. 109, 444 460.

Dean, W.E., 1999. The carbon cycle and biogeochemical dynamics in lake sediments. J. Paleolimnol. 21, 375-393.

deMenocal, P., Ortiz, J., Guilderson, T., Sarnthein, M., 2000. Coherent high- and low-latitude climate variability during the Holocene Warm Period. Science 288, 2198-2202.

Evert, M.J., 1980. Le lac Tanganyika, sa faune, et la peche au Burundi. Université du Burundi, Bujumbura.

Forester, R.M., Colman, S.M., Reynolds, R.L., Keigwin, L.D., 1994. Lake Michigan's Late Quaternary limnological and climate history from ostracode, oxygen isotope, and magnetic susceptibility. J. Great Lakes Res. 20, 93-107.

Gasse, F., 2002. Kilimanjaro's secrets revealed. Science 298, $548-549$

Haberyan, K.A., Hecky, R.E., 1987. The late Pleistocene and Holocene stratigraphy and paleolimnology of lakes Kivu and Tanganyika. Palaeogeogr. Palaeoclimatol. Palaeoecol. 61, 169-197.

Haug, G.H., Hughen, K.A., Sigman, D.M., Peterson, L.C., Röhl, U., 2001. Southward migration of the Intertropical Convergence Zone through the Holocene. Science 293, 1304-1308.

Herring, R.S., 1979. Hydrology and chronology: the Rodah Nilometer as an aid in dating interlactustrine history. In: Webster, J.B. (Ed.), Chronology, Migration and Drought in Interlacustrine Africa. Africana Publ. Co., New York, pp. 39-86.

Johnson, T.C., Barry, S.L., Chan, Y., Wilkinson, P., 2001. Decadal record of climate variability spanning the past $700 \mathrm{yr}$ in the Southern Tropics of East Africa. Geology $29,83-86$. 
Johnson, T.C., Brown, E.T., McManus, J., Barry, S., Barker, P., Gasse, F., 2002. A high-resolution paleoclimate record spanning the past 25,000 years in southern East Africa. Science 296, 113-132.

Johnson, T.C., Ng'ang'a, P., 1990. Reflections on a rift lake. In: Katz, B.J. (Ed.), Lacustrine Basin Exploration - Case Studies and Modern Analogs. Am. Assoc. Pet. Geol., Tulsa, OK, pp. 113-135.

Martens, K., 1985. Tanganyikacypridopsis gen.n. (Crustacea, Ostracoda) from Lake Tanganyika. Zool. Scr. 14, 221-230.

Martens, K., 1994. Ostracod speciation in ancient lakes: a review. In: Martens, K., Goddeeris, B., Coulter, G. (Eds.), Speciation in Ancient Lakes. Advances in Limnology. E. Schweizerbart'sche Verlagsbuchhandlung, Stuttgart, pp. 203-222.

Mourguiart, P., Carbonel, P., 1994. A quantitative method of palaeolake-level reconstruction using ostracod assemblages: an example from the Bolivian Altiplano. Hydrobiologia 288, 183-193.

Mourguiart, P., Corrège, T., Wirrmann, D., Argollo, J., Montenegro, M.E., Mourchet, M., Carbonel, P., 1998. Holocene palaeohydrology of Lake Titicaca estimated from an ostracod-based transfer function. Palaeogeogr. Palaeoclimatol. Palaeoecol. 143, 51-72.

Nicholson, S.E., 1996. A review of climate dynamics and climate variability in eastern Africa. In: Johnson, T.C., Odada, E.O. (Eds.), The Limnology, Climatology, and Paleoclimatology of the East African Lakes. Gordon and Breach, Amsterdam, pp. 25-56.

Nicholson, S.E., 1998. Historical fluctuations of Lake Victoria and other lakes in the northern rift valley of East Africa. In: Lehman, J.T. (Ed.), Environmental Change and Response in East African Lakes. Kluwer Academic, Dordrecht, pp. 736.

Nicholson, S.E., 2000. The nature of rainfall variability over Africa on time scales of decades to millennia. Glob. Planet. Change 26, 137-158.

O'Reilly, C.M., 2001. The effects of land use change on littoral zone dynamics in Lake Tanganyika, East Africa. Ph.D. Thesis, University of Arizona, Tucson, AZ, 144 pp.

Park, L.E., Cohen, A.S., Martens, K., Bralek, R., in press. The impact of taphonomic processes on interpreting paleoecological changes in large lake ecosystems: ostracodes in Lakes Tanganyika and Malawi. J. Paleolimnol. 30, in press.

Park, L.E., Martens, K., 2001. Four new species of Gomphocythere from Lake Tanganyika, East Africa (Crustacea, Ostracoda). Hydrobiologia 450, 129-147.

President's Office - Planning Commission, 1991. 1988 Population Census: Kigoma Regional Profile. Bureau of Statistics, Dar es Salaam.

Rome, D.R., 1962. Exploration Hydrobiologique du Lac Tanganyika, 3. Institut Royal des Sciences Naturelles de Belgique, Brussels, 305 pp.

Russell, J.M., Johnson, T.C., Kelts, K.R., Lærdal, T., Talbot, M.R., 2003. An 11,000-year lithostratigraphic and paleohydrologic record from Equatorial Africa: Lake Edward,
Uganda-Congo. Palaeogeogr. Palaeoclimatol. Palaeoecol. 193, 25-49.

Russell, J.M., Johnson, T.C., Talbot, M.R., in review. A 725yr cycle in the climate of Central Africa during the late Holocene. Geology.

Stager, J.C., Johnson, T.C., 2000. A 12,400 ${ }^{14} \mathrm{C}$ yr offshore diatom record from east central Lake Victoria, East Africa. J. Paleolimnol. 23, 373-383.

Stuiver, M., Reimer, P.J., Bard, E., Beck, J.W., Burr, G.S., Hughen, K.A., Kromer, B., McCormac, F.G., van der Plicht, J., Spurk, M., 1998a. INTCAL98 Radiocarbon age calibration 24,000-0 cal BP. Radiocarbon 40, 1041-1083.

Stuiver, M., Reimer, P.J., Braziunas, T.F., 1998b. High-precision radiocarbon age calibration for terrestrial and marine samples. Radiocarbon 40, 1127-1151.

Talbot, M.R., 2001. Nitrogen isotopes in palaeolimnology. In: Last, W., Smol, J. (Eds.), Tracking Environmental Change Using Lake Sediments. Volume 2: Physical and Chemical Techniques. Kluwer Academic, Dordrecht, pp. 401-440.

ter Braak, C.J.F., Smilauer, P., 1998. CANOCO Reference Manual and User's Guide to Canoco for Windows: Software for Canonical Community Ordination (version 4). Microcomputer Power, Ithaca, NY, $352 \mathrm{pp}$.

Thompson, L.G., Mosley-Thompson, E., Davis, M.E., Henderson, K.A., Brecher, H.H., Zagorodnov, V.S., Mashiotta, T.A., Lin, P.-N., Mikhalenko, V.N., Hardy, D.R., Beer, J., 2002. Kilimanjaro ice core records: evidence of Holocene climate change in tropical Africa. Science 298, 589593.

Verschuren, D., 2001. Reconstructing fluctuations of a shallow East African lake during the past 1800 yrs from sediment stratigraphy in a submerged crater basin. J. Paleolimnol. 25, 297-311.

Verschuren, D., in press. Decadal and century-scale climate variability in tropical Africa during the past 2000 years. In: Battarbee, R.W., Gasse, F., Stickley, C. (Eds.), PAGES-PEPIII: Past Climate Variability through Europe and Africa. Kluwer Academic Press, Dordrecht.

Verschuren, D., Laird, K.R., Cumming, B.F., 2000. Rainfall and drought in equatorial east Africa during the past 1100 years. Nature 403, 410-414.

Vincens, A., 1993. Nouvelle séquence pollinique du Lac Tanganyika: 30, 000 ans d'histoire botanique et climatique du Bassin Nord. Rev. Palaeobot. Palynol. 78, 381-394.

Wells, T.M., Cohen, A.S., Park, L.E., Dettman, D.L., McKee, B.A., 1999. Ostracode stratigraphy and paleoecology from surficial sediments of Lake Tanganyika, Africa. J. Paleolimnol. 22, 259-276.

Wouters, K., 1979. Kavalacythereis braconensis gen. n., sp. n. a remarkable new Cytheracean ostracod genus and species from Lake Tanganyika (Zaire). Ann. Soc. R. Zool. Belg. Brux. 108, 179-187.

Wouters, K., 1988. On Romecytheridea ampla Wouters sp. nov. Stereo-Atlas of Ostracod Shells 15, 101-106.

Wouters, K., Martens, K., 1992. Contribution to the knowledge of Tanganyikan cytheraceans, with the description of 
Mesocyprideis nom. nov. (Crustacea, Ostracoda). Bull. Inst. R. Sci. Nat. Belg. 62, 159-166.

Wouters, K., Martens, K., 1994. Contribution to the knowledge of the Cyprideis species flock (Crustacea: Ostracoda) of Lake Tanganyika, with the description of three new species. Bull. Inst. R. Sci. Nat. Belg. 64, 111-128.

Wouters, K., Martens, K., 1999. Four new species of the $C y$ prideis species flock (Crustacea: Ostracoda) of Lake Tanganyika. Bull. Inst. R. Sci. Nat. Belg. 69, 67-82.
Wouters, K., Martens, K., 2001. On the Cyprideis species flock (Crustacea, Ostracoda) in Lake Tanganyika, with the description of four new species. Hydrobiologia 450, 111-127.

Wouters, K., Martens, K., De Deckker, P., 1989. On the systematic position of Tanganyikacypris Kiss, 1961, with a description of T. stappersi sp. n. Courier. Forsch. Inst. Senckenberg 113, 177-186. 